\title{
ICEM2011-59214
}

\section{DIVISION OF NUCLEAR LIABILITIES BETWEEN DIFFERENT LICENSE HOLDERS AND OWNERS}

\author{
Staffan Lindskog \\ The Swedish Radiation Safety Authority \\ Stockholm, Sweden
}

\author{
Rolf Sjöblom \\ Waste Science \& Technology, \\ Luleå University of Technology, \\ Luleå, Sweden
}

\section{ABSTRACT}

Sweden was one of the first six countries to build and operate a nuclear power reactor. Thus, there exists a corresponding legacy in terms of liabilities for decommissioning and waste management of the historic facilities. Compliance with the Polluter Pays Principle (PPP) and its corollary on equity between generations implies that plans for decommissioning must be made and funds set aside for its execution. The need for precision in the cost estimates often governs the timing of the technical planning. Cost estimates are treacherous since cost raisers may be identified and evaluated only after considerable efforts have been made.

Further complications and challenges arise as a result of changes that take place between construction and decommissioning of facilities in terms of the entities involved as owners, operators, license holders, Authorities and financiers.

From this perspective, the present paper summarizes the general legislation as well as the legislation that applies particularly to nuclear activities. It also summarizes the relation between the nuclear decommissioning fund system and financial reporting.

Three examples are provided that wholly or partially fall under the Studsvik act (that specifically covers old facilities):

- The Ågesta nuclear power plant

- The Ranstad uranium mining and beneficiation facility

- The Neutron Research Laboratory at Studsvik

The findings include the following:

- It is important that the legislation be clear as to what is included and not.

- The rationale for the legislation should also be clear and well communicated.

- Old agreements can be significant for the assessment of liabilities, even in cases where a party may no longer exist.
- Support for assessment of when activities are continuing or not (which may have a strong significance for the liability) can be found in court cases on chemically contaminated soil.

- Analysis of facilities and the work carried out at different times can be very helpful in determining whether or not a facility is auxiliary.

- In order to be essentially correct, annual reporting must be coherent with the declarations of the funding system and in compliance with the IAR/IFRS standards.

- Keeping of searchable records is essential

- Research is essential, not only to provide bases for high quality decisions, but also to promote consensus based on agreement on factual circumstances

\section{INTRODUCTION AND RATIONALE FOR THE WORK}

In many countries, nuclear power constitutes a significant source of electric energy, and according to the statistics at the OECD/IEA Internet site, Sweden is "champion" among the OECD countries with its consumption of nuclear energy by 6.9 kWh per inhabitant during the year 2008. Moreover, Sweden was one of the six countries that took part in the rush to build nuclear power stations[1]. The other countries were United States, United Kingdom, France, Soviet Union and Canada. All other countries with nuclear power reactors have had to turn to either of these for assistance [1].

The early developments in Sweden focused on heavy water tank type reactors, and the Ågesta nuclear power reactor (see further below) located in the outskirts of Stockholm is a good example.

Much of the early work was carried out by AB Atomenergi at the Studsvik site, see Figure 1. The Ranstad uranium mining and beneficiation facility was in operation during 1965-1985. It was located in Skultorp near Skövde in southwest Sweden. 
Today, Sweden has 12 nuclear reactors (both PWR:s and BWR:s) taken into operation between 1972 and 1985, but two of them have been permanently shut down. In addition, there is a central store for spent nuclear fuel, CLAB, at the Oskarshamn nuclear site and a geologic final store for short-lived, and lowlevel waste, SFR, at the Forsmark site.

The old as well as the more recent activities have generated nuclear waste as well as contaminations of surfaces and media in buildings.

At present, it must be regarded as well known that decommissioning of nuclear facilities as well as the associated management of the waste constitute substantial undertakings and costs. It has e. g. been found [2-24] that early planning is essential, that the timing of the technical planning may be governed that for financial planning, and that such planning may be very treacherous, especially for older research facilities for which a long time might have passed after closure, e. t. c.

The main reasons for this are presented in References [12,17-18] in which it has been found that reasonably reliable cost estimates at an early stage can be obtained only if the following is used as a basis:
- Radiological surveying (total or via representative sampling)

- Technical planning and methodology selection. This includes to determine relations between capital / equipment and labour.

- $\quad$ Financial risk identification and evaluation

It can be noted in this regard that although nuclear chain reactions were introduced already in the 1940's, together with induced radioactivity, it took until the 1970's until the waste issue was recognized and attended to. A similar development has taken place for decommissioning, in which case the awareness has arisen more recently.

Part of the reason for the incubation or initiation time may be found in the development of the Polluter Pays Principle (PPP). It is e. g. dealt with in the Brundtland report[25] which refers to an OECD decision from 1972[26].

A corollary to the PPP is the principle of equity between generations (more on this topic can be found in [20]). These principles have been incorporated in various legislations, and have thus had a substantial influence on the issues of nuclear decommissioning and waste management, see further below.

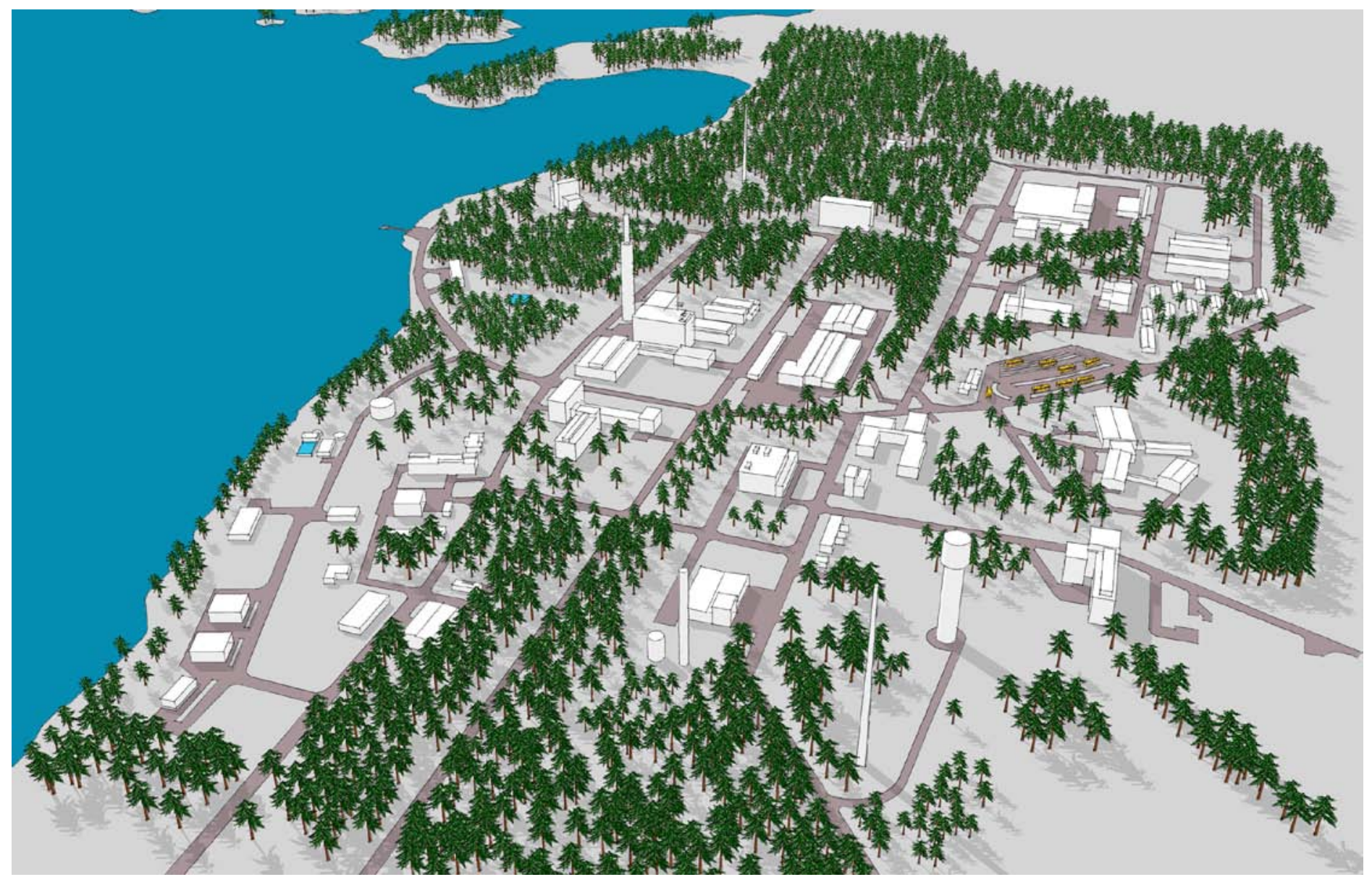

Figure 1. Artist's impression of the Studsvik site at around the year 1965. The illustration is based on contemporary drawings [2728] and areal photographs [28-31]. (The site looks substantially different today.) 
Analyses in a historical perspective have shown [23], however, that sustainability awareness has been around for at least as long as agriculture, and that some of the shortcomings are actually modern inventions. It has also been put forward that awareness does not necessarily arise promptly following a new discovery, but that there may be substantial delays involved.[24] In the strategic planning for the operation of a nuclear facility it is therefore essential to identify such discoveries or features that may become trends in some future.

Thus, although an early definition of the PPP was introduced in the Swedish legislation already in 1969[32-33], we are still struggling with its full implementation.

One aspect that has been dealt with in numerous court cases (in the area of chemically contaminated soil) is environmental liability with regard to owners, operators and license holders. They may have appeared in parallel or sequentially. The issue has also prompted action in the area of nuclear decommissioning and waste management.

The legislation in Sweden - as in many other countries states that it is possible - at least in theory - for the legal system to sue anyone of the license holders, operators and owners, and perhaps also others involved, for any damage or other liability. It might therefore be tempting to assume that the issue of who is responsible may not be very important. It is up to such parties to sort out in retrospect who is to pay what for which liability.

Actually, such an outcome should be seen as a last resort, and is thus more of an academic interest. As will be illustrated and shown below, appropriate and responsible environmental management relies on proactive actions and adequate early planning as well as good judgment and strive for consensus. Unclear responsibilities impede or prohibit appropriate timely action.

In our Swedish experience - in the area of chemically contaminated soil as well as in the area of nuclear technology these matters are highly significant for an efficient and successful implementation of the PPP. In spite of this, they are rarely presented and discussed in the scientific literature.

This is the rationale for the present work in which some of our experiences in the different areas are compiled and lessons learned shared.

\section{DISCLAIMER}

This paper refers to work in progress and as such any conclusions represent the views of the authors and do not necessarily reflect the views held by the Swedish Radiation Safety Authority.

\section{NOMENCLATURE}

There are three levels of legislation in Sweden.

1 Law which is issued by the Parliament and as authorized by the people in Sweden

2 Ordinance which is issued by the Government, under the laws issued by Parliament and after authorization by the Parliament
3 Regulation which is issued by a Competent Authority such as the Swedish Radiation Safety Authority. A regulation is issued under the laws and ordinances and after authorization by the Government.

Laws, ordinances and regulations are legally binding and the compliance of them is overseen and assured by our legal system, including our courts.

In addition, a Swedish Authority may be delegated to issue general advice with regard to a certain regulation. It can contain clarification as to what the actual regulation is intended to mean and may also provide examples. General advice is not legally binding and compliance must not necessarily be upheld in a court decision.

Competent Authorities - like everybody else, e. g. a branch organization - can also issue guidance documents. They reflect good practice, but cannot necessarily be relied on for compliance with legislation.

In this paper, the Swedish Radiation Safety Authority (in Swedish: Strålsäkerhetsmyndigheten) is referred to by its abbreviated name, SSM.

\section{DECOMMISSIONING UNDER THE GENERAL LEGISLATION}

Framework legislation relevant for decommissioning can be found in the Swedish environmental code[34] together with the introduction of the environmental code act[35].

The PPP is implemented in the Swedish Environmental code[34] as follows: "Persons who pursue or have pursued an activity or taken a measure that causes damage or detriment to the environment shall be responsible, until such time as the damage or detriment ceases, for remedying it to the extent deemed reasonable ...”. There is no limit in time, nor in extent. Thus, the full liability will exist as long as remediation has not been completed.

The same principle, albeit less comprehensive, can be found in the environment protection act[32-33] which was in force from 1969 to 1998 at which time it was replaced with Swedish environmental code[34-35].

Liability for environmental damage is not subject to barring by limitation. However, since the Swedish instrument of government[36] states that legislation cannot apply retroactively, responsibility is claimed only for such damages that originate from activities that have continued after the 30th of June 1969[35] when the environment protection act[32-33] came into force.

The Swedish instrument of government[36] also states that lex in casu is not allowed and that decisions in individual cases can be made only by our legal courts. Consequently, questions of what damage should be paid by whom has been the subject of considerable investigations and advice, see e. g. [37-41], as well as rulings in the environmental courts, see e. g. [42].

Thus, the extent of the responsibility that can be claimed from an operator depends on the following factors: 
- the extent of remedial action required

- when the damage was inflicted

- earlier requirements on the operator (e. g. by permits for operation and court decisions)

- compliance with present and previous legislation

- if the damage could reasonably have been foreseen

The responsibility is a collective one, and can be demanded from any entity involved. Responsibility is demanded from operators before owners, and from late operators before early ones. It is then up to the parties to come to agreement on how the liabilities are to be distributed among them.

The courts usually make their assessments in two steps. Firstly, they consider and decide on what is the appropriate extent of the remedial actions to be taken, and secondly, on how much of this that can reasonably be demanded from the operators and owners.

For activities carried out before the year 1969, this may imply that none of the operators and owners can be held liable for at least part of the costs. In such cases, remediation cannot come about unless the Government supplies the financing that is missing. For such purposes, the Swedish Environment Protection Agency receives on the order of $40 \mathrm{M} €$ annually.[43] According to the latest annual report of the Agency, the developments are mainly positive, but the pace of remediation must increase if the risks associated with contaminated sites are to be controlled before the year 2050 .

Thus, the timing of remedial actions depend not only on what may be optimal from health and environment as well as sustainability and technical feasibility points of view, but also on the availability of financial resources.

Guarantees for funding are achieved by means of requirements on securities as one of the conditions for licensing.[34] This includes municipalities, as decided in a recent court ruling by Miljööverdomstolen (our highest court that deals with environmental cases), decision M5292-09.

Although there is comprehensive legislation for nuclear technology activities, see below, the conventional environmental legislation, cf. above, applies simultaneously. There are a few exceptions, however, including that securities need not be provided under the Swedish environmental code[34] if funding is assured under the act of financing[44].

\section{DECOMMISSIONING UNDER THE NUCLEAR LEGISLATION}

Nuclear technology is regulated in Sweden primarily under the following laws:

- Radiation protection act[45]

- Act on nuclear activities[46]

- Nuclear liability act[44]

- The Studsvik act that covers the Swedish nuclear legacy for certain old facilities before 1991.[47]

The main purpose of the nuclear liability act is to provide for the adequate financing and appropriate responsible action for decommissioning and waste management from the Swedish nuclear power program described above in the introduction, see references [9-24,48-49].

Recently, the nuclear liability act as well as its associated ordinance[50] have included also license holders of small facilities.[18] In addition, a special law - commonly referred to as the Studsvik act - was introduced in 1988 to cover decommissioning and waste management for certain historical facilities.[47] Most of the facilities included in the law are at the Studsvik site, including the R2 research reactor and its "auxiliary buildings", but the Ågesta reactor and the Ranstad facility are also included, see further below.

There have been operator and ownership related issues in conjunction with the system of finance concerning the nuclear power plants, but the main attention so far has been paid to issues related to the Studsvik act and the new ordinance that includes also small facilities. Therefore, this will be dealt with in the following.

The nuclear liability act[44] was first issued in 1981 and covered only the nuclear power reactors in operation and the associated waste. Other activities on decommissioning and waste management had until the late 1980's been financed out of the annual national budgets. This had been the case e. g. for the decommissioning of the R1 research reactor in Stockholm during the first part of the 1980's.[12,17] At that time Studsvik $\mathrm{AB}$ was owned to $100 \%$ by the Swedish state, and also owned the entire Studsvik site.

In 1987, the Government proposed to Parliament[51] that a separate fund should be established for the financing of decommissioning and waste management associated with certain historical facilities, and that the payments to this fund should be made by the nuclear utilities in proportion to their generation of nuclear electricity. It was reasoned in the proposition that Studsvik AB (mainly under its previous name $\mathrm{AB}$ Atomenergi) had played a major part in the development of nuclear power technology from which other actors subsequently were reaping the benefits. It was only fair, according to the proposition, that those actors - the operators of the nuclear power plants - paid for the associated environmental liability. The proposal on policy from 1987[51] was followed up during the subsequent year in the form of another proposition to the Parliament[52] which lead to the decision on the Studsvik act[47].

The rationale put forward by the Government may, however, not represent an entirely coherent view in Sweden. It is thus put forward in a report published by the Swedish Nuclear Fuel and Waste management Company (SKB) on the Swedish nuclear waste programme[53] that the reason for the new law was that Studsvik $A B$ had encountered financial problems.

This is not an argument that was put forward in the policy proposition from 1987[51]. It is noted elsewhere in the proposition that Studsvik AB should receive a shareholder contribution of SEK 40 million which can be compared with the estimated environmental liability under the Studsvik act which 
(according to the same proposition) amounted to SEK 1500 million. Thus, there is little support in the original document for the claim in the SKB report.

Comparison may also be made with the Government expenditures on nuclear R\&D during 1955-1975 which in today's currency amount to a total of about SEK 18000 million[54] (corresponding to about 1,9 billion $€$, and to about SEK 10000 million at the price level of 1988). It should also be realized that considerable work was conducted on decommissioning and waste management related to historical legacies during the 1980 's, but the monetary extent has not been assessed in the present work.

It is of course very difficult to assess if a court ruling such as those that have come about after the introduction of the environmental code ten years later[34] (c. f. above) might have facilitated less diverging perspectives. It can be concluded, however, that the Studsvik act has lead to that responsible action has been taken with regard to the environmental liabilities of historical facilities, and that the Swedish nuclear community can pride itself of compliance with the PPP.

During the years 2003-2004, the nuclear liability act[44] and the Studsvik act[47] were subject to a public investigation[55]. The present analysis is limited to the implications for the Studsvik act. It was proposed that the Studsvik act was to be closed on the grounds of the Swedish instrument of government[36] not allowing lex in casu (legislation for individual cases) together with the desirability of a unified legislation. It has not been possible for the present authors to extract what actual benefits this would imply with regard to the pertinent implementation of the PPP for the historical nuclear liability. The investigation discusses uncertainty, but no trace has been found in the main text regarding the uncertainty of assessments for historic facilities relative to other costs. Grounds for such assessment can, however, be found in the appendices in which e. g. Shankar Menon puts forward that there are particularly large uncertainties in the estimations of costs for decommissioning. Almost one year before the investigation was published, the competent Authority (then the Swedish Nuclear Power Inspectorate, now SSM) published reference [9] which could also have substantially improved the perspective regarding the uncertainties involved.

The possible implications of the premature closing of the Studsvik fund were presented in some detail at a meeting in 2008.[15]

Subsequently, the Studsvik fund has been reopened twice and the latest decision was passed by Parliament in late June 2011. Now, the Studsvik law will apply through the year 2017. Furthermore, AB SVAFO (which is owned by the Swedish nuclear utilities) is the entity carrying out most of the remedial actions. Nowadays, AB SVAFO owns most of the facilities that they are responsible for, and this reduces the nuclear liability risks for the now publicly traded Studsvik AB to more ordinary levels.
The latest version of the Studsvik act (yet not published, but decided by Parliament in accordance with the proposition)[56] clarifies that the Neutron Research Laboratory is as an auxiliary building to the R2 research reactor, and is thus to be included in the financing. It also clarifies that it is waste generated before June 30, 1991, that is to be included. The Government proposition and Parliament decision are based on an investigation carried out by SSM.[57]

As earlier, and contrary to the nuclear liability act[44], the Studsvik act contains no mentioning of repayment of superfluous funds. However, the Government puts forward that it considers the prerequisites for such repayments. It is the intention of the Government that the fee should cover only the actual costs incurred which implies that very limited contingencies (if any) should be included in the fee.

Before it was presented to the Parliament, the proposed new version of the Studsvik act was reviewed by the Council on Legislation which did not identify any issues related to lex in casu.

The public investigation[55] also lead to certain changes in the nuclear liability act[44] and to a new ordinance[50] (in the year 2008), the implications of which were presented at the previous ICEM meeting[50]. In essence, it clarifies how the nuclear liability as defined already under the environmental code[34] is to be managed. It states that all license holders under the act on nuclear activities[47] have to carry out recurrent cost calculations, which are reviewed by SSM, and to pay to segregated funds and/or to provide securities as decided by SSM.

\section{THE FUND SYSTEM AND FINANCIAL REPORTING}

The ordinance[50] mentioned in the previous section implies that Studsvik $\mathrm{AB}$ and a few others will have to make such calculations and pay to segregated funds for those liabilities that are not covered under the Studsvik act.

There are as to yet no national detailed instructions regarding how such calculations are to be made. Guidance can be found, however, in the international literature since ASTM has published standards on assessments[58] and disclosure[58] of costs for decommissioning. IFRS/IAS has issued a standard for financial reporting[60] that is valid in many countries, including Sweden. Further references can be found in [18]

According to IAS 16[60], costs for "asset dismantlement, removal and restoration" should be included in the "cost for an item of property, plant and equipment". Such costs are thus to be written off simultaneously with the other costs for the asset in question.

IFRIC 1 in [60] "applies to changes in the measurement of any existing decommissioning, restoration or similar liability ...". Such "changes in the liability shall be added to, or deducted from, the cost of the related asset in the current period". "The amount deducted from the cost of the asset shall not exceed its carrying amount" and "the excess shall be recognised immediately". "If the adjustment results in an addition to the cost of an asset, the entity shall consider 
whether this is an indication that the new carrying amount of the asset may not be fully recoverable". The issue of impairment of assets is dealt with in IAS 36[60] which states that "if the recovered amount of an asset is less than its carrying amount, the carrying amount shall be reduced to its recoverable amount. That reduction is an impairment loss" ... "and shall be recognised immediately". Please note that this is only a collection of quotes, and that the full text of the latest version of IAS/IFRS should always be consulted.

In practice, it may well be that a sudden recognition of the decommissioning costs for an old facility can lead to a substantial reduction in profit for the current year. This may not always be the case, however, since such decomissioning costs can be balanced against surplus values.

\section{EXAMPLES}

\section{Background}

A brief historical background to the examples below can be found in the introduction. Further information is available in [15] and references therein.

In the year 1988, as a consequence of the Parliament decision on the Studsvik act, Studsvik AB formed the subsidiary Atomenergi Projekt $A B$ to carry out the decommissioning and waste management work. In 1992, these tasks were taken over by $A B$ SVAFO which was owned by the Swedish nuclear utilities. Studsvik AB acquired AB SVAFO in 2003 but sold it back to the utilities in 2009. In parallel to these developments, AB SVAFO has taken over licenses and ownerships for facilities that fall under the Studsvik act. The latest example is the acquisition of the permanently shut down research reactor R2.

\section{The Ågesta nuclear power plant}

The Ågesta nuclear power was of the tank type and had heavy water as coolant and moderator. The thermal output was $65 \mathrm{MW}$ of which 10 were converted to electricity, and 55 were utilised as district heating for part of Stockholm. It was in operation during 1963-1974. The reactor was contaminated by severe fuel damages, and the damaged fuel was sent abroad for treatment. Details on the Ågesta reactor may be found in $[15,61]$.

Certain preparations for decommissioning were made at the time of the AKA investigation[62-64] in the mid 1970's which turned the reactor into a suitable state for maintenance at a low level for many years. The actions included removal of all the fuel, the heavy water and any readily removable radioactive items. The primary system of the reactor was decontaminated in the early 1990's.[65]

The Agesta nuclear power reactor is located on a real property owned by the City of Stockholm. Originally, the reactor and auxiliary buildings were owned to $50 \%$ by Vattenfall $\mathrm{AB}$ and to $50 \%$ by Studsvik AB (disregarding changes of names of the owners). Today, AB SVAFO has taken over the shares held by Studsvik AB. The licence to operate the facility is presently held by Vattenfall AB. AB SVAFO has, however, made a request to the SSM to take over the licence, and it is intended that AB SVAFO also takes over the shares held by Vattenfall $\mathrm{AB}$ after it has assumed responsibility for the license.

The original version of the Studsvik act[47] included only activities related to Studsvik AB, and thus clearly excluded the $50 \%$ owned by Vattenfall AB. This reference was dropped in the revision of the Studsvik act in 2006 (Proposition 2005/06:183 and SFS 2006:651), and therefore the Vattenfall AB liability is - as far as is our understanding - no longer formally excluded. This appears to be entirely unintentional, however, since no discussion can be found on the matter, and since Vattenfall $\mathrm{AB}$ has made payments to the Nuclear Waste Fund in accordance with a $50 \%$ liability under the nuclear liability act[44,50,66].

The Ranstad uranium mining and beneficiation facility

The Ranstad facility was in full operation during 19651969. A total of 215 tonnes of uranium were produced (corresponding to about seven weeks of operation of the present Swedish nuclear power plants). One million cubic meters of tailings were generated. The site of the excavation is now a lake having an area of 27 hectares.

The rock type is alum shale which in its richest layers contain around $0.03 \%$ of uranium. The uranium was beneficiated by leaching with sulfuric acid and subsequent liquid-liquid extraction.

For this and further information, see References[67-69]

The plant was owned and operated by AB Atomenergi (now Studsvik AB). In 1977, LKAB and Boliden AB formed the R\&D company $A B$ Svensk Alunskifferutveckling (ASA) which they owned by $50 \%$ each. The name literally translates to "Swedish Alum Shale Development Limited Company". The Subsequent year ASA formed a subsidiary named Ranstad Skifferaktiebolag (RSA). The name literally translates to "Ranstad Shale Limited Company". It was owned to $60 \%$ by ASA and to $20 \%$ each by LKAB and Studsvik Energiteknik AB (formerly AB Atomenergi, now Studsvik AB). Simultaneously, RSA took over the facilities and personnel from Studsvik Energiteknik AB.

Reference [68] states the following about this takeover: "When RSA was established and took over the Ranstad plant in 1978, the agreement included a clause that Studsvik Energiteknik $A B$ maintained responsibility for restoration of areas affected by the earlier uranium production. Consequently Studsvik Energiteknik $A B$ took charge of draining and waste water treatment at Ranstad as well as of preparations for final restoration from fiscal year 1984/85 with special government financing until the end of 1988."

The present authors have not had access to the text of the agreement, but it is still a fair assumption that the authors had excellent insight into the events since one of them (Gunnar Olsson) was the general manager at the Ranstad site for many years.

The quotation thus strongly suggests that the environmental liability from the historical use of the Ranstad site remained solely with Studsvik Energiteknik AB regardless of subsequent 
ownership of the site. Thus, the introduction of the Studsvik act[47] and its explicit mentioning of Ranstad a few years later implies that all the historic liabilities fall under this act.

In 1984, the Swedish government made the decision to stop all plans for uranium production in Sweden and the Ranstad uranium license was cancelled.[69] According to [68], RSA/ASA decided to stop all activities with alum shale when their license expired. The localities were let out to other companies, and one of them, Ranstad Industricentrum $A B$, acquired RSA in 1987.

The above shows that Ranstad Industricentrum $A B$ could neither have had the intent nor the possibility to continue the previous uranium mining and beneficiation activities. This relates, at least in principle, to the court cases[42] discussed above in which a sharing of liabilities may come into question for ongoing activities.

After the introduction of the Studsvik act, further remediation and decommissioning work was carried out at the Ranstad site including putting a cover on the 25 hectares of tailings and the demolition of some of the buildings[68-69], and, more recently, cleaning up with regards to remaining chemicals e t c.

Ranstad Mineral AB is renting facilities at Ranstad Industricentrum $\mathrm{AB}$. The two companies have the same owner. According to Reference [70], Ranstad Mineral AB, in collaboration with Studsvik $A B$, reprocesses waste containing enriched uranium. The waste is first incinerated at Studsvik where after the ashes are leached with sulphuric acid at Ranstad. According to [70], "The process started in a small scale 1984. During 1998 - 2000 about 150 ton material was processed each year. The production of uranium each year was $700-800 \mathrm{~kg}$. The leaching residues had uranium contents $<0,02 \%$. With these low values combined with the strong leaching with sulfuric acid it has been possible to dispose these leaching residues at a municipal waste disposal facility."

Arguments against seeing this as the same and ongoing activity relative to the previous uranium mining and beneficiation include the following:

- the purpose is entirely different,

- the latter annual turnover has been around 150 tonnes as compared with on the order of 500 thousand tonnes, and

- there was more or less a discontinuity in time of 15 years (between 1969 and 1984)

Information on the present historical facilities and the associated cost estimations can be found in [71-72]. The license for the Ranstad site is held by Ranstad Industricentrum AB. According to its latest annual report, AB SVAFO intends to work with the license holder through agreements.

\section{The Neutron Research Laboratory at Studsvik}

The R2 research reactor at Studsvik was in operation between 1960 and 2005 when it was permanently shut down. The enrichment of the uranium fuel was much higher than for power reactors. It was a light water cooled and moderated reactor of tank type design. The core was only about one meter in cube but had a maximum thermal power output of about 50 MW.

The design was very versatile with regard to the types of experiments and services that could be performed: fuel ramp tests, materials tests, irradiation of materials for electronics, cancer treatment, chemical analysis by neutron activation, and generation of various particles - especially neutrons - for scientific experiments.

The operation of the reactor was thus synergetic with the operation of the Neutron Research Laboratory (NRL) which consequently had to close after the shut down of the R2 reactor. The equipment used by NRL was partly located around the core of the reactor, partly in an adjacent building.

Examples of headings in the progress report from of NRL from 1987-1989 include the following:

- Neutron Scattering Activities form materials research

- Neutron and X-ray Scattering

- Studies of Materials

- Neutron Diffraction Research

- Neutron Scattering Projects for Reactor Physics

- Experimental Subatomic Physics, in particular Neutron Physics

- Physical Biology

The license of operation is held by the University of Uppsala. The building is owned by Akademiska Hus AB which is an organization that manages buildings for universities, and the real estate (the ground) is owned by Studsvik AB.

The University of Uppsala has fulfilled - as far as we have understood - its duty to decommission its laboratory as a tenant. This is as it should be, namely that remediation has been carried out in a timely manner and when there is still staff available who know about the work that has been conducted.

Recently, the question has arisen as to who should pick up the bill. Is their laboratory next to the reactor building such an auxiliary building as is mentioned in the Studsvik act[47]? If not, who should pay, the present license holder or previous ones? For a long time the laboratory was financed directly by what is now the National Research Council. Can a Research Council - a non-profit organization with no assets of its own be held responsible for environmental liabilities accumulated over time as a result of their grants?

Interviews with former staff together with information searches on the activities of NRL, including previous annual reports, indicate that little contamination has been added since the Studsvik act was passed. The remaining question is then if the laboratory in the adjacent building was auxiliary. For the execution of the research it was necessary to utilize the facilities in the laboratory simultaneously with those in the reactor hall. The conclusion in the present report is therefore that it is an auxiliary building. This is also what SSM has responded to the Government, and what parliament decided in June 2011, in accordance with a proposal from the Government.[56] 


\section{FINAL REMARKS}

It has been concluded earlier that cost calculations of decommissioning, especially of historic research facilities, is associated with considerably higher uncertainties as compared to other corresponding non-nuclear construction or demolition projects. Cost raisers are numerous, and may be difficult to identify beforehand. Compliance with the PPP implies that funds need to be accumulated during the useful life time in order to be available at the time when they are needed. Therefore, in many cases, the timing of the technical planning may be governed by the needs for financial planning.

During the time that passes between the erection of a facility and the issuing of a letter of end of responsibility, it can be expected that many changes take place with regard to the entities involved as owners, operators, license holders, Authorities, and financiers. The situation easily becomes complex which in turn may lead to disparities in views and associated conflicts. The issue of sorting out responsibilities between different organizations is by no means a new one in the international literature. Hard earned experience can e. g. be found in the area of outsourcing[73]. One important issue is to declare and sort out the responsibilities for any liabilities between different organizations, especially when changes are made in ownership.

It is essential in this regard to learn from experience, and to share lessons learned. Research is essential for the compilation and analysis of the factors that are important. This can also help the various parties with the knowledge bases needed for comprehensive perspectives.

Such support is essential not only for a high quality in the decisions, but also in order to build consensus based on agreement on factual circumstances.

The long-term character of the tasks is also a decisive factor. This calls for solutions that stand the tests of time with regard to e. g. public values and the state of scientific knowledge. Thus, stake-holders, e. g. the younger generation and scientists, need to be included in the decommissioning work. In this way, responsible action as well as societal acceptance may be achieved.

\section{REFERENCES}

1 Controlled nuclear chain reaction, the first 50 years. American Nuclear Society, 1992.

2 Decommissioning of nuclear power plants and research reactors. Safety Guide. IAEA safety standard series No WS-G.2.1.6

3 Decommissioning of Nuclear fuel cycle facilities. Safety Guide. IAEA safety standard series No WS-G.2.4.7

4 Decommissioning of medical, industrial and research facilities. Safety Guide. IAEA safety standard series No WS-G.2.2.8

5 Decommissioning Nuclear Power Plants: Policies, Strategies and Costs. Nuclear Energy Agency, Organization for Economic Co-operation and development, OECD / NEA, 2003.

6 European Union Recommendation "on the management of financial resources for the decommissioning of nuclear installations, spent fuel and radioactive waste". Brussels, 24 October 2006. C(2006)3672.

7 Standard Guide for Nuclear Facility Decommissioning Plans. ASTM standard E1281 89(2005).

8 Decommissioning Handbook. Procedures and practices for decommissioning. Office of Environmental Management. U.S. Department of Energy, Washington, D.C. 20585, USA. DOE/EM-0383, January 2000.

9 Sjöblom, R., \& Lindskog, S., An applied study of the storage for old intermediate level waste at the Studsvik site. SKI Report 2004:11. The Swedish Nuclear Power Inspectorate, February 2004.

10 Sjöblom, R., Sjöö, C., Lindskog, S. and Cato, A. Early stage cost calculations for determination and decommissioning of nuclear research facilities. The 10th International Conference on Environmental Remediation and Radioactive Waste Management. Glasgow, Scotland, 48 September, 2005.

11 Sjöblom, R., Sjöö, C., Lindskog, S. and Cato, A. Cost studies on decontamination and dismantling of nuclear facilities; the interim storage for spent nuclear fuel. (In Swedish: Kärntekniska kostnadsstudier avseende dekontaminering och nedläggning; Mellanförvaret för använt kärnbränsle i Studsvik). SKI Report 2006:20. The Swedish Nuclear Power Inspectorate, April, 2006.

12 Iversen, K., Salmenhaara, S., Backe, S., Cato, A. and Lindskog, S., Callander, C., Efraimsson, H., Andersson, I., Sjöblom, R. Cost calculations at early stages of nuclear facilities in the Nordic Countries. The 11th International Conference on Environmental Remediation and Radioactive Waste Management. September 2-6, 2007, Bruges (Brugge), Belgium

13 Cato, A., Lindskog, S. and Sjöblom, R. Financial Planning as a Tool for Efficient and Timely Decommissioning of Nuclear Research Facilities. American Nuclear Society. Decommissioning, Decontamination and Reutilization. Capturing Decommissioning Lessons Learned. September 16-19, 2007, Chattanooga, Tennessee, USA.

14 Lindskog, S., Cato, A., and Sjöblom, R. Estimations of costs for dismantling, decommissioning and associated waste management of nuclear facilities, and associated impact on decision processes, functioning of markets and the distribution of responsibilities between generations. WIT Transactions on Ecology and the Environment, Vol 108, pp 97-105, 2008.

15 Lindskog, S., and Sjöblom, R. Regulation evolution in Sweden with emphasis on financial aspects of decommissioning. Decommissioning. Challenges: an Industrial Reality? Sept. 28 to Oct.2, 2008 - Avignon, France. 
16 Laraia, M. and McIntyre, P. J., responsible officers; Cato, A., Lindskog, S. and Sjöblom, R. et al contributors. Decommissioning of research reactors and other small facilitiesby making optimal use of available resources. IAEA Report Series 463, Vienna 2008.

17 Andersson, I., Backe, S., Iversen, K., Lindskog, S., Salmenhaara, S. and Sjöblom, R., Cost calculations for decommissioning and dismantling of nuclear facilities. Nordic Nuclear Safety Research, Project NKS-R, Report number NKS-165, July 2008. ISBN 978-87-7893-230-3.

18 Lindskog, S. and Sjöblom, R. Radiological, technical and financial planning for decommissioning of small nuclear facilities in Sweden. Proceedings of the 12th International Conference on Environmental Remediation and Radioactive Waste Management, ICEM2009, October 1115, 2009, Liverpool, UK.

191 Lindskog, S. and Sjöblom, R. Implementation of the polluter pays principle - example of planning for decommissioning. WIT Transactions on Ecology and the Environment, Vol 131, pp 27-38, 2010.

20 Labor, B. and Lindskog, S. Values held by young stakeholders on financial planning regarding liabilities for nuclear decommissioning. WIT Transactions on Ecology and the Environment, Vol 131, pp 235-246, 2010.

21 Lindskog, S., Sjöblom, R. and Labor B., Sustainability of nuclear energy with regard to decommissioning and waste management. WIT Transactions on Ecology and the Environment, Vol 143, pp 303-314, 2011.

22 Sjöblom, R. and Lindskog, S. Management of international environmental liabilities - example of decommissioning of nuclear research and development facilities. International Journal of Sustainable Development \& Planning, in print.

23 Lindskog, S., Labor, B. and Sjöblom, R. Sustainability of nuclear energy with regard to decommissioning and waste management. Submitted to International Journal of Sustainable Development \& Planning.

24 Sjöblom, R., Lindskog, S. and Andreas, L., Lessons learned from nuclear decommissioning and waste management relevant to end of responsibilities for landfills. To be presented at Sardinia 2011, Thirteenth International Waste Management and Landfill Symposium.

25 Brundtland, G., Chairman, Our Common Future (The Brundtland report). World Commission on environment and Development, Oxford University Press, Oxford, United Kingdom, 1987.

26 See OECD. 'Guiding Principles Concerning International Economic Aspects of Environmental Policies', Council Recommendation C(72)128, Paris, 26 May 1972.

27 Munche, J-F., The architect in the nuclear age. Design of buildings to house radioactivity. Iliffe Books Ltd., London, 1964.

28 Studsvik, Swedish research establishment. EuroNuclear, September, 1965.

29 Österlundh, C. G. \& Erwall, L. G., Erzeugung und Anwendung von Radioisotopen. (In German; Production and use of radioisotopes) Die Atomwirtschaft, February, 1963.

30 Aler, B., Survey of Sweden. Nuclear Engineering International, September 1970.

31 Bladh, R., and Eriksson, O., 40 år i Studsvik. (In Swedish; 40 years at Studsvik). Studsvik AB.

32 Miljöskyddslag (Environment Protection Act, in Swedish). SFS 1969:387. This law was in force from 1969 to 1998 at which time it was replaced with Miljöbalken (the Swedish environmental code).

33 Sand, P. H. Legal systems for environment protection; Japan, Sweden, United States. Legislative studies No. 4. United Nations, Food and Agriculture Administration, May, 1972. This reference contains a translation of Miljöskyddslagen.

34 The Swedish Environmental Code. English translation. Ds 2000:61. Chapter 2, section 8. (In Swedish Miljöbalk, SFS 1998:808)

35 Lag om införande av miljöbalken. (Introduction of the environmental code act, in Swedish). SFS 1998:811.

36 Regeringsformen. (The instrument of government, in Swedish). SFS 1974:152.

37 Förorenade byggnader - undersökningar och åtgärder. (Contaminated buildings - investigations and remedial actions, in Swedish) Report 5491. Swedish Environmental Protection Agency, November, 2005.

38 Om ansvar för miljöskulder i mark och vatten Miljöbalkens regler om skyldigheter och ansvar för förorenade områden. (On responsibility of environmental liabilities in soil and water. The rules in the environmental code on duties and responsibilities for contaminated areas, in Swedish). Report 5242. Swedish Environmental Protection Agency, January, 2003.

39 Delfinansiering av efterbehandlingsobjekt genom avtal/överenskommelse. (Joint financing of remediation projects through agreements, in Swedish). Report 5490. Swedish Environmental Protection Agency, April, 2006.

40 Säkring av efterbehandlingsåtgärders effekt över tiden. (Ensurance long-term performance of remedial actions, in Swedish). Report 5757. Swedish Environmental Protection Agency, November, 2007.

41 Efterbehandling av förorenade områden. Vägledning för planering och genomförande av efterbehandlingsprojekt. (Remediation of contaminated sites. Guidance for planning and execution of remediation projects. In Swedish). Report 4803. Swedish Environmental Protection Agency, February, 1998.

42 Examples of relevant decisions from Miljööverdomstolen (the highest court that deals with environmental cases in Sweden): M491-09, M768-01, M2535-08, M5292-09, M5338-04, M5664-09, M5939-01, M6231-09, M6940-05, M8489-09, M8552-03, M9298-08, M9822-02, M9894-05, M9894-05. 
43 Naturvårdsverkets årsredovisning 2010. (Annual report, in Swedish). Swedish Environmental Protection Agency, February, 2011.

44XG Lag om finansiella åtgärder för hanteringen av restprodukter från kärnteknisk verksamhet. (Nuclear liability act, in Swedish). SFS 2006:647. (The original version of this law had reference SFS 1981:669.)

45 .Strålskyddslag. (Radiation protection act, in Swedish). SFS 1988:220.

46 Lag om kärnteknisk verksamhet. (Act on nuclear activities, in Swedish:). SFS 1984:3.

47 Lag om finansiering av hanteringen av visst radioaktivt avfall $\mathrm{m}$. $\mathrm{m}$. (Act on financing of certain radioactive waste e. t. c., in Swedish). SFS 1988:1597.

48 O. Söderberg. In the shadow of the nuclear power debate around 1980 - thoughts on the birth of the finance system of today. (In Swedish). In Nuclear waste - costs and financing (Swedish title: Kärnavfall - kostnader och finansiering). Swedish National Council for Nuclear Waste. SOU 2005:83. ISBN 91-38-22439-9.

49 O. Söderberg et al. Decommissioning Funding: Ethics, Implementation, Uncertainties. A Status Report. OECD/NEA Report no 5996, 2006. ISBN 92-64-02312-7.

50 Förordning om finansiella åtgärder för hanteringen av restprodukter från kärnteknisk verksamhet. (Ordinance on financial action for the management of residues from nuclear technology activities, in Swedish). SFS 2008:715.

51 Regeringens proposition om energipolitik inför 1990-talet. (The proposition of the Government on energy policy for the 1990's, in Swedish). Proposition 1987/88: 90.

52 Regeringens proposition om finansieringen av hanteringen av visst radioaktivt avfall $\mathrm{m}$. $\mathrm{m}$. (The proposition of the Government on financing of the management of certain radioactive waste e. t. c., in Swedish). Proposition 1988/89:37.

53 Kjellman, S. Det svenska kärnavfallsprogrammet. (The Swedish nuclear waste program, in Swedish). Swedish Nuclear Fuel and Waste management Company, December, 2000.

54 Fjæstad, M., and Jonter, T., The Rise of the Nuclear System of Innovation in Sweden. Svenska ekonomisk-historiska mötet i Stockholm 2007.

55 Betalningsansvaret för kärnavfallet. (The financial responsibility for the nuclear waste, in Swedish.) SOU 2004:125, December 2004.

56 Avgift enligt Studsvikslagen. (Fee according to the Studsvik act, in Swedish). Proposition 2010/11:126.

57 Standard Guide for Estimating Monetary Costs and Liabilities for Environmental Matters. ASTM Standard E 2137 - 06, December 2006.

58 Regeringsuppdrag att utreda effekter av den s.k. Studsvikslagens upphörande. (Commission from the Government to investigate the effects of termination of the Studsvik Act, in Swedish). SSM 2009/4123.
59 Standard Guide for Disclosure of Environmental Liabilities. ASTM Standard E 2173 - 07, April 2007.

60 International Financial Reporting Standards and International Accounting Standards (IFRS/IAS). International Accounting Standards Board. 2008. (New versions are published every year).

61 McHugh, B., editor. The Ågesta nuclear power station. A staff report by AB Atomenergi. Stockholm, 1964.

62 Radioactive waste. Interim report about low and intermediate level radioactive waste from the AKA public investigation. (In Swedish) Department of Industry, Ds I 1975:8. ISBN 91-38-02742-9.

63 Spent nuclear fuel and radioactive waste. A summary report given by the Swedish Government committee on radioactive waste. AKA public investigation. (English summary of AKA Reports I-III in Swedish)) Department of Industry, SOU 1976:32. ISBN 91-38-02973-1.

64 Spent nuclear fuel and radioactive waste. Parts I and II. AKA public investigation. (In Swedish) Department of Industry, SOU 1976:30 and SOU 1976:31. ISBN 91-3802971-5 and ISBN 91-38-02972-3, respectively.

65 Varley, G. Ågesta-BR3 Decommissioning Cost Comparison and Benchmarking Analysis SKI Research Report 2003:11. Swedish Nuclear Power Inspectorate, November, 2002.

66 Kärnavfallsfonden. Verksamhetsberättelse 2010. (Swedish Nuclear Waste Fund. Annual report 2010, in Swedish).

67 Strandell, E. editor. Uran ur skiffer, Ranstadverket. (Uranium from shale, the Ranstad plant, in Swedish). Printing financed by AB SVAFO, 1998.

68 Hultgren, A. and Olsson, G. Uranium recovery in Sweden, history and perspective. SKB Arbetsrapport 93-42. Swedish Nuclear Fuel and Waste Management Company, August, 1993.

69 Ehdwall, H. A short review of Swedish uranium mining, milling and restoration in Ranstad. In "Planning for environmental restoration of radioactively contaminated sites in central and eastern Europe Volume 1". Proceedings of a workshop held within the Technical Co-operation Project on Environmental Restoration in Central and Eastern Europe in Budapest, Hungary, 4-8 October 1993. IAEA-TECDOC-865.

70 Lorenzen, J., Lindberg, M., Lövstrand, J. and Lilljha, B. Handling and treatmant of uranium cintaminated combustible radioactive low level waste (LLW). WM'02 Conference, Tucson, Arizona, USA, February 24-28, 2002.

71 Varley, G. A Review of the decommissioning costs of the Ranstad site. SSM Research 2009:31. Swedish Radiation Safety Authority, August, 2009.

72 Varley, G. A On decommissioning costs of the Ranstad site. SSM Research 2010:23. Swedish Radiation Safety Authority, August, 2010.

73 Guidelines for process safety in outsourced manufacturing operations. Center for chemical process safety of the American institute of chemical engineers, 2000. ISBN 08169-0812-5. 